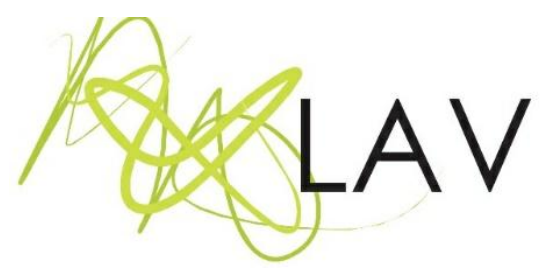

\title{
Expositions of 'degenerate' art and music in nazi Germany: reflections on totalitarian aesthetics and education
}

\author{
Exposições de arte e música "degeneradas" na Alemanha nazista: reflexões sobre \\ estética totalitária e educação
}

\author{
Guilherme Prado Roitbergi \\ Universidade Federal de São Carlos (UFSCar) \\ Fabiana Maria Baptistai \\ Universidade Estadual Paulista (UNESP) \\ Luiz Roberto Gomesiii \\ Universidade Federal de São Carlos (UFSCar)
}

\begin{abstract}
During the Third Reich (1933-1945), Nazi intellectuals conceived the music and the plastic arts as elements that form moral values, which can corrupt education and compromise political and social life. From the theoretical formulation of a totalitarian aesthetic, every art considered "degenerate" was censored and exposed as an example of immorality. Inaugurated in 1937, the exhibitions Entartete Kunst (Degenerate Art) and Entartete Musik (Degenerate Music) brought to the city of Munich works related to modernism, Bolshevism, as well as the artistic production of black people, Jews and Soviets. Based on a bibliographic research supported by the Critical Theory of Society, this article analyzes the content of those exhibitions, demonstrating the pedagogical role of art in the formation of the moral values of German society from the perspective of Nazi intellectuals.
\end{abstract}

Keywords: Degenerate art, Nazism, education, totalitarian aesthetics, Critical Theory of Society.

\section{Resumo}

Durante o Terceiro Reich (1933-1945), os intelectuais nazistas conceberam a música e as artes plásticas como elementos formadores de valores morais, podendo corromper a educação e comprometer a vida política e social. A partir da formulação teórica da estética totalitária, toda arte considerada "degenerada" passou a ser censurada e exposta como exemplo de imoralidade. Inauguradas em 1937, as exposições Entartete Kunst (Arte Degenerada) e Entartete Musik (Música Degenerada) trouxeram até a cidade de Munique obras ligadas ao modernismo, ao bolchevismo, bem como a produção artística de negros, judeus e soviéticos. Com base em uma pesquisa bibliográfica amparada pela teoria crítica da sociedade, o presente artigo analisa o conteúdo dessas exposições, demonstrando a caráter pedagógico da arte na formação dos valores morais da sociedade alemã, sob a ótica dos intelectuais nazistas.

Palavras-chave: Arte Degenerada, nazismo, educação, estética totalitária, teoria crítica da sociedade. 
Hopefully, the bright flame of our enthusiasm never dies out. Only this flame gives light and heat to the creative art of modern political propaganda. Rising from the depths of the town, this art must always come back down on it and find its strength there. Gun-based power can be a good thing; it is, however, better, and more satisfying to win the heart of the people and keep it.

Speech by Joseph Goebbels, minister of Nazi propaganda (KRACAUER, 1985, pp.281-282).

\section{Introduction}

The purpose of this article is to analyze the relationship between art and education in the exhibitions Entartete Kunst (degenerate art) and Entartete Musik (degenerate music), inaugurated in 1937 in the city of Munich, during the German Nazi fascist regime. Our work will be based on texts, images and documentaries about the history of Germany during the Third Reich period (1933-1945) - the period in which the country was under the command of Adolf Hitler (1889-1945) - in dialogue with authors who addressed on the question of history, art and education in the totalitarian regimes of the first half of the twentieth century. We consider that from the historical perspective we can identify the main guiding axes and the fundamental characteristics of the Nazi formation project. At first, the aim is to demonstrate how Nazi intellectuals sought to maintain a close relationship between education and art, considering their pedagogical role in shaping the moral values of German society. Finally, we will bring to the debate the critiques of the totalitarian model of education based on Theodor Adorno (1903-1969) from his theory of semi formation ${ }^{1}$.

Analyzing a complex period like the Third Reich is a task that brings us several challenges. To follow this path, the contextualization of Germany is necessary before and during the period of World War II (1939-1945). The Third Reich was the period when Adolf Hitler $^{2}$ ruled the country after the Weimar Republic (1918-1933), when Germany

\footnotetext{
1 In opposition to a critical and emancipating cultural formation (in German, Bildung), semi formation (Halbbildung) would comprise an education based on a model of totalitarian rationality, reproducing authoritarianism, insensitivity, bourgeois coldness, hatred and violence (ADORNO, 2010). The concept will be explained in detail throughout the article, where we will outline not only the context of its production by the critical theorists of the University of Frankfurt, but also its relevance to the field of Education.

${ }^{2}$ We do not intend to make a lengthy exposition here about the life of Adolf Hitler. However, some notes about his rise to power are necessary for the development of our work. Born in Austria in 1889, Hitler was a military man active in World War I (1914-1918), who closely followed the political events of Germany during the conflict and later, with the signing of the Treaty of Versailles and the establishment of the Weimar Republic, between 1919-1933, period of strong economic and political crisis that preceded his rule. He was arrested in 1923 after a failed coup attempt; a year later, he wrote his career in the book Mein Kampf, published in 1925 and 1926. In 1933 he was appointed chancellor, leading the Federal Government of Germany; months later, backed by strong popular support and an efficient radio propaganda apparatus, a referendum would seal his victory, giving him full powers to act autonomously. The death of president Paul Hindenburg (1847-1934) would consolidate Hitler's rise
} 
experienced a serious economic and social crisis (the value of the national currency - the Reichsmark - came close to zero). This situation was aggravated by the signing of the Treaty of Versailles (1919), which considered Germany to be the major culprit of the First World War (1914-1918), imposing a series of restrictions and punishments on the country ${ }^{3}$. This series of retaliations, added to all the economic impacts of the 1929 crisis, during which the capitalist world economy seemed to collapse, paved the way for the emergence of an authoritarian ideology, inspired by Benito Mussolini's Italian fascism (1883-1945). In the case of Germany, fascism was "a reaction to the trauma of the Great Depression and the inability of the Weimar governments to cope" (HOBSBAWM, 1995, p.131).

Authors such as Kracauer (1985) and Bartoletti (2006) agree that Adolf Hitler's rise to power was grounded in the authoritarian mindset that had been developing in the country since the late nineteenth century. For many years, this rise of authoritarian rule and speech would be seen as the great salvation for the problems of the German people, which had been suffering from political instability, the economic crisis and the humiliation of defeat in World War I. Although it appeared as an attempt to establish a democratic government, the Weimar Republic passed insecurity and instability to the Germans, who lacked strong leadership to resolve the chaotic situation in which the country lived. Thus, both Italian and German fascism, as well as other radical right movements in the first half of the twentieth century were the result of the correlation of various factors such as the reaction to liberalism (in other words, the accelerated transformation of capitalism), the rise of the working-class movements inspired by the Russian Revolution of 1917 and the mass migration of foreigners to Europe, intensifying xenophobia in the form of antiSemitism that became stronger from the second half of the nineteenth century (HOBSBAWM, 1995). Norbert Elias (1997) would include alongside economic issues the inability of the Weimar Republic to deal with the crisis of the self-image of the German people, which allowed the formation of an authoritarian mentality that despised parliamentary democracy, longed for a central authority and a strong state that could restore the pride that once existed in Germany, thus paving the way for the construction of the Third Reich.

as Führer (supreme leader, head of the Nazi Party), while being both Reich President (head of state) and Reich Chancellor (head of government) (BARTOLETTI, 2006).

${ }^{3}$ Among numerous penalties imposed on Germany, the Treaty of Versailles - signed by the World War I winning countries, especially France, England and the United States of America - held the Germans responsible for the outbreak of the war, mandating the payment of millionaire compensation to the winning countries, the assignment of strategic territories such as the Alsace-Lorraine region, the recognition of Austria's independence, limited the national army, arms industry and imposed a heavy fine of 132 billion German marks on the German state (BARTOLETTI, 2006).

Revista Digital do LAV - Santa Maria - vol. 13, n. 3, p. 97 - 113 - set./dez. 2020 ISSN 1983 - 7348 http://dx.doi.org/10.5902/1983734848141 
Under the aegis of national socialist ${ }^{4}$ totalitarianism ${ }^{5}$, German citizens were not free to come and go and say what they thought. Political opponents were persecuted, communists were killed daily. Propaganda was used to persuade the German people to accept censorship and mass murder of opposition movements. Radio stations and newspapers were censored, as well as art, a fundamental element in building the ideological foundations of Nazism. Under the command of the Reich Minister of Propaganda Joseph Goebbels (1897-1945), music, the fine arts, sports, and architecture should meet the interests of the National Socialist Party, as Contier (1988) states:

During the period of the authoritarian regimes of the 1930s and 1940s, some governments sought to establish official projects in the field of culture, at a time when popular music was greatly expanded through radio and records. At that moment music reached all social classes, becoming a danger in favor of the penetration of alien cultures, capable of putting in check the national populist principles, the ideological sustaining shades of these states (CONTIER, 1988, p. 112-113).

The consolidation of a totalitarian ideology and aesthetics was one of the main aspects sought by German intellectuals through a new model of education. From 1933, all content taught in schools and universities followed the guidelines of the Ministry of Science, Education and National Culture, under the command of Minister Bernhard Rust (18831945) (SHIRER, 1990). In this context, the works of authors considered as harmful to the regime began to be censored and burned in public square ${ }^{6}$. Teachers should join the Masters Alliance of National Socialism, defend the German state and train students on party principles, otherwise they could be fired and even beaten publicly (BARTOLETTI, 2006). Backed by the discourses, advertisements, and theories that preached Aryan superiority over other peoples of the world7, intellectuals such as physicists Rudolf Tomaschek (1895-1966) and Johannes Stark (1874-1957), mathematician Ludwig Bieberbach (1886-1982), Hitler Youth official (Hitlerjugend) Baldur Benedikt von Schirach (1907-1974), German Young Women League (Bund Deutscher Mädel) psychologist and leader Jutta Rüdiger (1910-2001) and Minister Bernhard Rust himself extended to the

\footnotetext{
${ }^{4}$ Expression used to refer to the German Nazi Party - officially the National Socialist Party of German Workers (Nationalsozialistische Deutsche Arbeiterpartei) - or just the National Socialist Party.

${ }^{5}$ In Cambi's (1999, p. 577) definition, "a totalitarian state is an authoritarian, bureaucratically organized state run by a single party capable of controlling and unifying in a common action project the whole of society, without waste", founded on a "ideologically compact, rigidly structured model, committed to conforming the masses to party-state objectives".

${ }^{6}$ During 1933, the Nazi party organized a series of library looting and book burning in Germany. The extensive list of censored authors included names such as Thomas Mann, Helen Keller, Jack London, Walter Benjamin, Bertolt Brecht, Sigmund Freud, Albert Einstein, Karl Marx, among others (KNUTH, 2003).

7 According to historian Eric Hobsbawm (1917-2012), the ideals of German superiority had existed in Germany since the second half of the nineteenth century and were strengthening in the first half of the twentieth century, especially with the development of the branch of applied genetics, "which dreamed of creating a human super race by selective breeding and the elimination of the incapable" (HOBSBAWM, 1995, pp.121-122). In a similar perspective, Friedlander (1995, pp.18-19) states that the holocaust was only possible thanks to the scientific acceptance of eugenics and anti-Semitism by anthropologists, geneticists, psychiatrists and physicists (including teachers, assistants and students) at German universities still in the early twentieth century.
} 
camp of Education the racist and anti-Semitic policy of racial hygiene (Rassenhygiene) and, subsequently, the policy of extermination (Vernichtungspolitik) (SHIRER, 1990), that had already been outlined by Adolf Hitler in the chapter "People and Race" from his Mein Kampf:

The role of the strongest is to dominate. It should not be mixed with the weak, thus sacrificing its own greatness. Only the weak born can see this as cruelty, which is explained by its weak and limited complexion [...]. Numerous proofs of this provides us with historical experience. With astonishing clarity, she demonstrates that in every blood mix between the Aryan and inferior peoples the result has always been the extinction of the civilizing element. North America, whose population is decidedly for the most part made up of Germanic elements, which have very little mingled with inferior and colored peoples, has a different humanity and culture than Central and South America, where the immigrants, almost all Latinos, merged in large numbers with the indigenous inhabitants. Such an example would suffice to recognize the effect of the fusion of races clearly and distinctly. The German of the American continent rose until its domination, because it was kept purer and without mixture; there he will continue to reign until he is victimized by the sin of the mixture of blood. In few words, the result of crossbreeding is therefore always as follows: A) Lowering of the level of the strongest race; B) Physical and intellectual return and thus the onset of a slowly but surely progressing disease. To provoke such a thing, then, is nothing but an attack on the will of the Creator. Punishment also corresponds to sin (HITLER, 2016, p. 212-213).

\section{Guided by the Führer's ${ }^{8}$ idea}

I of education and the orientations of the National Socialist Party, the Ministry of Science, Education and National Culture - whose intellectuals were called "racial experts" (Rassenkundler) - organized German educational reform out of drastic curricular change, based on the insertion of new disciplines, among which were "Racial Science" and "Eugenics". Racial Science classes taught young people that the Aryans were the superior race (Herrenrasse) and that God had sent them strong to rule a weak world. In Eugenics classes students were taught not to "mix blood", that is, they were instructed to believe that Aryans should only marry and relate to other Aryans in order to maintain the purity of their superior race (BARTOLETTI, 2006). They also learned how to identify Jews by physical traits "inferior" to Aryan traits, such as nose size and circumcision marks. In universities, deans, professors, and study groups were subject to the centralization of the Ministry, while youth associations and student unions were linked to the Hitler Youth fronts; resistance groups - such as the anti-Nazi White Rose movement (Weiße Rose) organized by the brothers Hans Scholl (1918-1943) and Sophie Scholl (1921-1943) - were persecuted by the secret police (Gestapo) and their members were condemned to death (SHIRER, 1990, p.919).

\footnotetext{
${ }^{8}$ According to Bartoletti (2006, p. 40-41), Hitler "had precise ideas about education": his main goal was for all Germans to have the same "worldview" (Weltanschauung), that is, "education had the sole purpose of turning children into good Nazis."
} 
With this centralizing, hierarchical, bureaucratic, authoritarian, and militarized dynamic, education in the Third Reich became the main spokesperson for Nazi-fascist ideology. As Cambi points out (1999, p. 577), although Italian fascism pioneered the construction of a totalitarian ideological education project (extending from school to major universities, including the press), it was German Nazism "which outlined the most organic and coherent system of mass ideological education", based on "racist and militaristic principles, capable of involving all the growth of young generations, through family, school and extra-school". Thus, it was justified the organization of exhibitions and cultural events to educate the German population on the ideas of Nazi-fascism and to avoid the "deviations" attributed to social groups considered "degenerate", as we shall see below.

\section{The pedagogical role of art in Nazi Germany: the exhibitions Entartete Kunst and the Entartete Musik}

Alongside the moral education of young Germans through the Hitler Youth ${ }^{9}$, art was one of the main elements of ideological formation and Nazi propaganda ${ }^{10}$. Directed by filmmaker Leni Riefenstahl (1902-2003), the 1935 documentary Triumph des Willens presents the 6th Nazi Party Congress, held in 1934 in Nuremberg. From the analysis of this work and the advertisements portrayed in Peter Cohen's (1989) documentary Architecture of Destruction (Undergångens arkitektur), we can see how art, especially cinema, was widely used as a means of implanting Nazi idealism as a guide to the moral conduct of the German citizens.

The fine arts, music and architecture were part of this centralizing dynamic of Nazi intellectuals, which determined the parameters to be strictly adhered to by German artists. The attempt to rescue the ideals of beauty of Classical Antiquity - especially of Greece was demonstrated with each speech of the Führer in his visits to art exhibitions. For Adolf Hitler, Greece represented the noblest ideal of beauty, an archetype that was to be transplanted to Germany and followed by the Aryan race. The model of the "perfect body"

\footnotetext{
${ }^{9}$ Founded in 1926, the Hitler Youth (Hitlerjugend) was a political organization aligned with the National Socialist Party, created to guide the moral education of educated boys and girls to serve their Führer under any circumstances. It was based on strict military discipline, controlled physical and intellectual activities, organized military marches in various German cities and, above all, preached the total submission of young people to the leaders of the Nazi party. Hitler saw in this youth "a powerful political force that would help shape Germany's future", taking advantage of "their enthusiasm and loyalty" (BARTOLETTI, 2006, pp.13-14), which is why, after the rise of the Third Reich in 1933, entry into Hitler Youth make it compulsory for all young Germans.

${ }^{10}$ Mass-oriented propaganda was one of the biggest concerns of Nazi intellectuals and Führer himself. In his Mein Kampf, Hitler stated: "I understood from the outset that the proper application of an advertisement is a true art... [...] The end of advertising is not one's scientific education, but rather to draw the attention of the mass to certain facts, needs, etc., whose importance thus only falls within the visual circle of the mass. [...] The art of propaganda lies precisely in understanding the mentality and feelings of the mass. It finds in a psychologically certain way the way to the attention and heart of the people" (HITLER, 2016, pp.135-138).
} 
of Greek sculptures - especially the Myron's Discobolus - and the ideal of military prowess of the ancient Spartan people had enchanted the Führer since his youth (COHEN, 1989). From these ideals Hitler pursued his colossal architectural designs, based on the return to classical antiquity through the theft of Greek statues and the construction of grand monuments and imposing buildings, executed by the young architect Albert Speer (19051981) (HOBSBAWM, 1995). However, the practice of theft of works of art as a way of legitimizing the historical origins of modern states was not unique to Nazism.

The looting, which was common in wartime since antiquity, was present during the medieval Crusades, later with the sacking of Amerindian peoples by the Europeans, until the period of modernity. The French general Napoleon Bonaparte (1769-1821) took in his expeditions to Egypt scientists and specialists responsible for confiscating cultural goods and taking them safely to France. In the same period, the British government sent archaeologists to confiscate Greek and Egyptian archaeological sites, notably the works of Italian archaeologist Giovanni Belzoni (1778-1823). This practice intensified with nineteenth-century neo-colonialism, when thousands of historical and archaeological monuments were removed from their places of origin and brought to the museums of the great world powers of the time, especially the British Museum in England, the Louvre Museum in France and the museums in Berlin and Pergamon in Germany. This issue has sparked a series of controversies, prompting countries affected by these practices to demand the return of works (as in the case of the Protocols of the Hague Conventions of 1954 and 1999 for the Protection of Cultural Property in the Event of Armed Conflict) with the support UNESCO, which considered the right to repatriation of works as a possibility of preserving the historical memory of these countries ${ }^{11}$. Thus, the return to antiquity was one of the main elements of the totalitarian aesthetics of the early twentieth century, affecting not only architecture and the plastic arts, but also the field of music, as Contier (1988) points out:

\begin{abstract}
The bureaucrats of the authoritarian regimes of the 1920 s and 1930 s took up concepts inherited from Ancient Greece about the art-citizen relationship. For the Greeks, music was part of their personality, of undeniable educational value, leading Plato, for example, in "The Republic" to raise questions about extremely strict control and regulation over music. Thus, each Greek mode represented a specific ethical value: the Doric, virility; the Phrygian, sobriety; the various modalities of Lydian, cheerfulness. According to these moral values, modes could exert corrupting influences on customs, even presenting risks to political and social life. From this problematic, the musical technique always relied on a certain system implicitly linked to cultural and ideological values varying according to the historical moment (CONTIER, 1988, p. 112).
\end{abstract}

\footnotetext{
${ }^{11}$ On the issue of looting cultural goods promoted by European countries, see Burleigh (2007), Cuno (2008), Ferreira (2014), Gombrich (2013) and UNESCO (1999).
}

Revista Digital do LAV - Santa Maria - vol. 13, n. 3, p. 97 - 113 - set./dez. 2020 ISSN 1983 - 7348 http://dx.doi.org/10.5902/1983734848141 
Resistance to avant-garde movements and modern art was another hallmark of Nazi censorship in the artistic field. As far as music is concerned, American jazz - "a kind of combination of black Americans, syncopated rhythmic dance music and unconventional instrumentation by traditional standards" (HOBSBAWM, 1995, p. 183) - represented an affront to music and German dances, being considered, along with the dancing rhythm of the swing, as "jungle music", danced and played by and for "degenerated" blacks. Regarding the fine arts, the cutting-edge innovations of the early twentieth century especially Dadaism and Surrealism - were largely repressed by the Third Reich. Dadaism, characterized as a protest the artistic standards of the time and against World War I, focused on shocking lovers of "traditional bourgeois art" (HOBSBAWM, 1995, p. 179), reason why his works were apprehended in the 1930 s and its traits attributed to a mental and moral degeneration of the artists that made up the movement.

Alongside the repression of black music, Dadaism and avant-garde movements that spread across Europe after the end of World War I, the closure of the Bauhaus School of Architecture in $1933^{12}$ demonstrated the clear antimodernist appeal of the Nazi aesthetic conception. According to Miranda (2007):

The events that culminated in the Nazi attack on modern art began to draw in 1927, in essays published by Alfred Rosenberg, ideologist of Hitler's party. Gathered under the title Der Sumpf (The Swamp), they accused the avant-garde aesthetics of representing a disease of the soul, imbalance and alienation, and the result of the combination of the money of capitalism and the mass culture maneuvered by the communists. Rosenberg's thinking exacerbated part of his feeling for the direction art had taken since the late 19th century and which had crossed the First World War. [...] Thus, by the time the Nazis came to power on January 30,1933, the fate of modern art was already traced. Jewish or opposition artists and intellectuals were removed from public office. Supporters of modern art were removed from the direction of museums and cultural institutions (MIRANDA, 2007, p. 36).

In addition to all the propaganda apparatus and the hundreds of exhibitions that reinforced what would be genuinely German art, the "other side" - that is, art harmful to the values of national socialism - also needed to be made explicit to the German people, compared side by side with what was considered good, beautiful and right, according to the Nazi aesthetic conception. To this end, the Reich Minister of Propaganda Joseph Goebbels and artistic director Adolf Ziegler (1892-1959) were tasked with organizing an art exhibition containing works by black, Jewish, Soviet, and modernist (Cubist and Dadaist) artists. Inaugurated on July 19, 1937 at the Hofgarten Gallery in Munich, these

\footnotetext{
12 Formed as an avant-garde school of art and design, Bauhaus started in Weimar, then moved to Dessau in Central Germany, being dissolved by the Nazis after Hitler came to power (HOBSBAWM, 1995). Nazi advocates pressured the government to close the school, accusing the institution and its students of disobeying the determinations imposed by Nazi aesthetic standards, thus being an "anti-German" school and therefore dangerous for the German nation (GOMBRICH, 2013).
} 
exhibitions were named Entartete Kunst (Degenerate Art) and Entartete Musik (Degenerate Music).

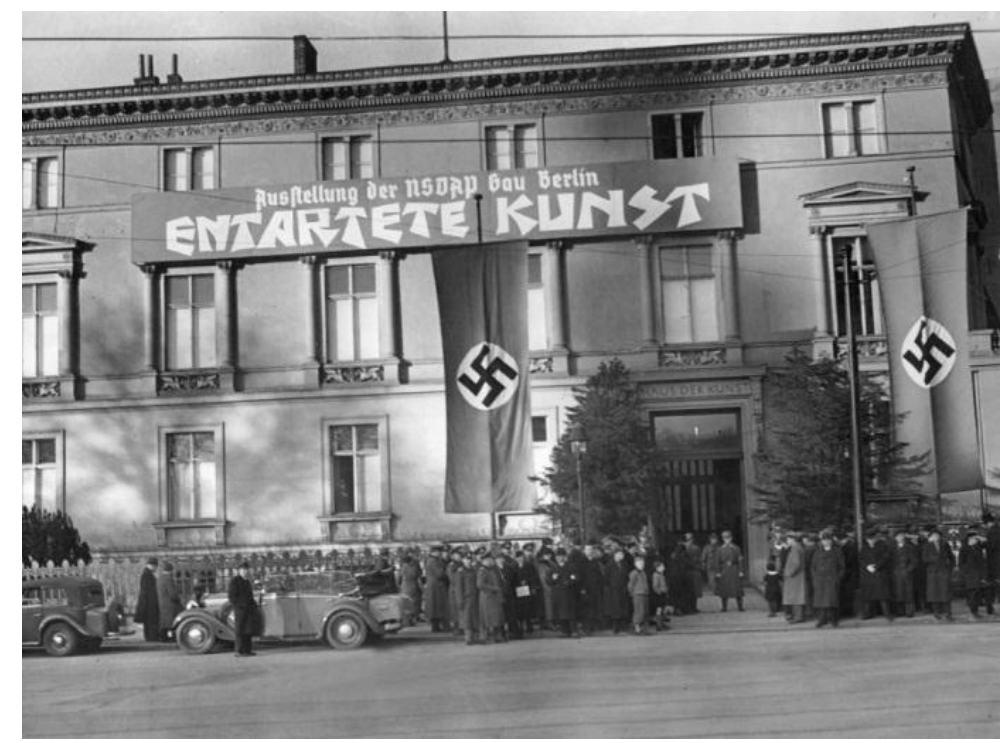

Image 1 - Facade of the exhibition Entartete Kunst. Source: Deutsches History Museum (DHM). ${ }^{13}$

Featuring a collection of about 650 works confiscated by the Nazis in various German and other European museums, the exhibition featured works by artists such as Pablo Picasso (1881-1973), Paul Klee (1879-1940), Marc Chagall (1887- 1985), Piet Mondrian (1872-1944), Wassily Kandinsky (1866-1944), Henri Matisse (1869-1954), Edvard Munch (1863-1944), Emil Node (1867-1956), Giorgio de Chirico (1888-1978), Georg Grosz (1893-1959), Georges Braque (1882-1963) and Ernst Ludwig Kirchner (1880$1938)^{14}$. In their posters, it was possible to observe the aesthetic formulation of what was considered harmful to the German people: the irrationality and "bestiality" of modernism as a symbol of the Entartete Kunst; Entartete Musik's posters were far less subtle about racism and anti-Semitism, presenting the public with a suit-clad monkey playing the saxophone - clothing and instruments typical of black jazz musicians of the 1920 s and 1930s - and prominently carrying a Star of David on his lapel, one of the main symbols used to identify Jews.

\footnotetext{
13 The images presented throughout the article were obtained from the Deutsches History Museum (DHM) collections; Germany History Documents and Images (GHDI) and the United States Holocaust Memorial Museum (USHMM), indicated with their respective acronyms in the bibliographic references.

14 The exhibition Entartete Kunst was filmed by American filmmaker and documentary filmmaker Julien Hequembourg Bryan (1899-1974), who captured through his lens scenes of everyday life in Nazi Germany during the period 1935-1938. Part of his collection was donated to the Library of the United States Congress of 1966; In 1995 this collection was acquired by the United States Holocaust Memorial Museum (USHMM), constituting an important material for studies on the subject. Available at https://www.ushmm.org/online/film/display/detail.php?file_num=1248 (Accessed 10/11/2020). Part of the collection can also be seen in Peter Cohen's (1989) documentary Architecture of Destruction (Undergångens arkitektur).
} 


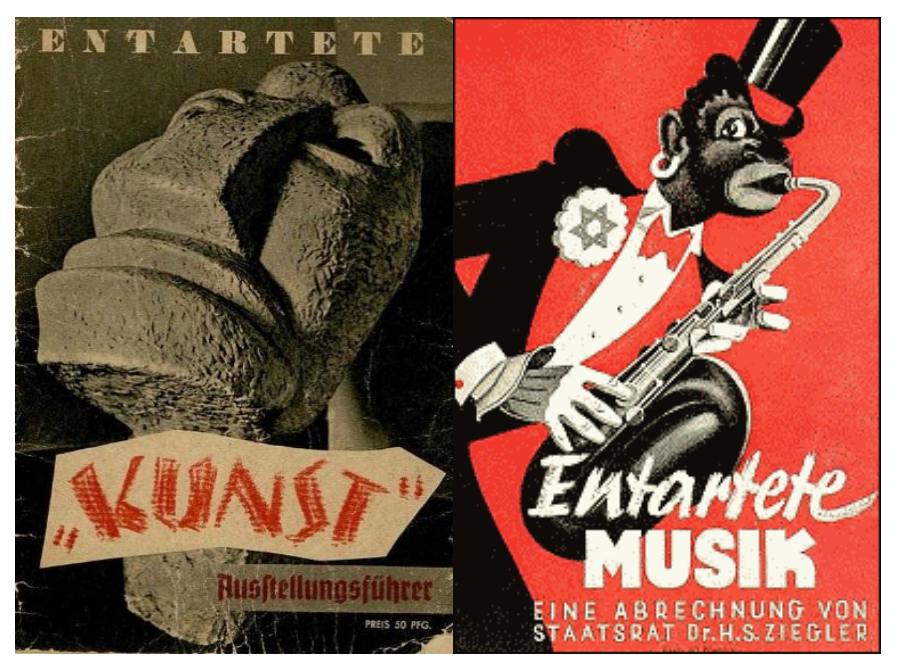

Images 2 and 3 - Posters of the exhibitions Entartete Kunst and Entartete Musik. Sources: Deutsches History Museum (DHM); Germany History Documents and Images (GHDI).

The exhibition remained open for visitation in Munich until November 30, 1937 and was later taken to other German cities. In the grand opening speech, director Adolf Ziegler stated: "Around us is the monstrous fruit of insanity, recklessness, ineptitude and complete degeneration. What this exhibition offers inspires horror and aversion in all of us" (MIRANDA, 2007, p. 36). With advertisements on radios, posters and pamphlets, the popularity of the exhibition was soon to be watched by millions of people from various parts of Germany and closely followed by both Joseph Goebbels and Adolf Hitler himself.

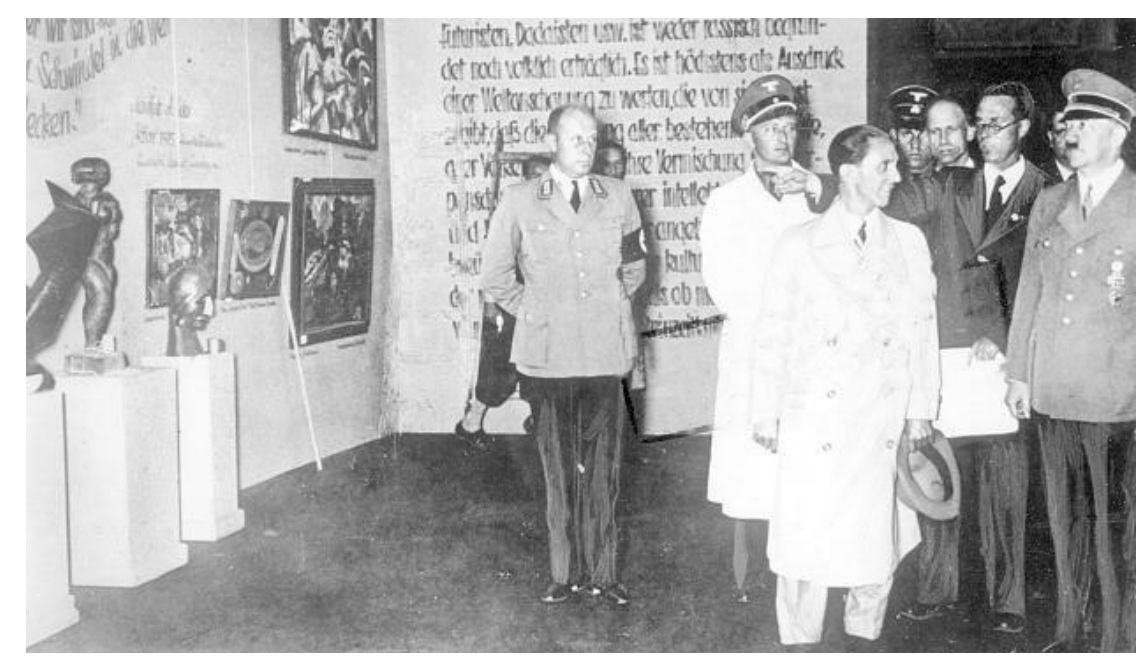

Image 4 - Adolf Hitler and the Reich Minister of Propaganda Joseph Goebbels visiting the exhibition Entartete Kunst.

Source: United States Holocaust Memorial Museum (USHMM).

Organized to instruct the German population on the basis of the ideals of the National Socialist Party, these exhibitions made clear the way Nazi intellectuals worked on 
the issue of modern art before the German population: to demonstrate the ideals of beauty of the Aryan race through large exhibitions - such as the exhibition of the Great German Art inaugurated in the same year - and in return, exposing in an unorganized and chaotic manner all that was linked to modern art, seen as the result of the degeneration of races, thus a real threat to moral integrity and social life of the German people. For its creators, this contraposition would educate the Germans according to socialist national interests, making explicit the moral values to be followed from the contemplation of "genuinely German" art and, on the opposite extreme, those aesthetic and moral values that should be fought by the population itself, aware of the dangers of "degenerate art" for the development of Germany.

During the exhibition, paintings and sculptures were scattered over the museum's walls, hung in a crooked manner, accompanied by texts with negative criticism, in order to appear disorder and make clear what was considered unacceptable according to Nazi ideals. The images of cubist or abstract paintings were placed alongside real images of the physically and mentally handicapped, demonstrating how this type of art was linked to a pathological issue, contributing to reinforce the social hygiene policy proposed by doctors and $\mathrm{SS}^{15}$ officers, where every disease or transmitting agent should be isolated and exterminated, ensuring the full health and development of the German social body.

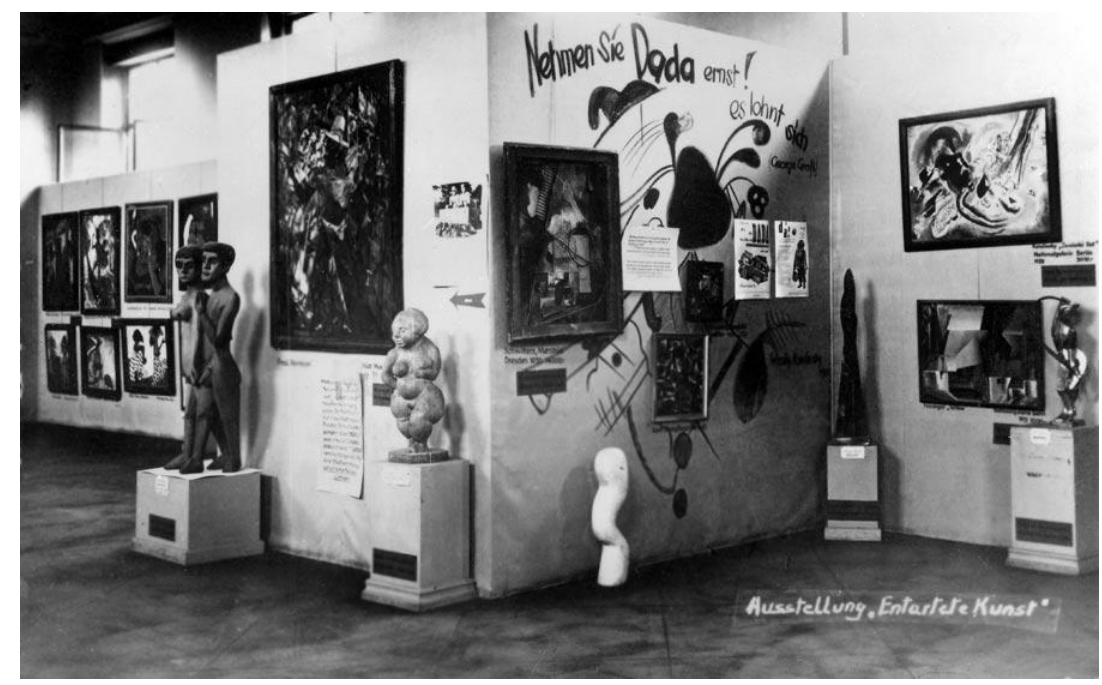

Image 5 - Exhibition Entartete Kunst in detail.

Source: United States Holocaust Memorial Museum (USHMM).

${ }^{15}$ Abbreviation for Schutzstaffel, Nazi Germany's leading extermination group. 


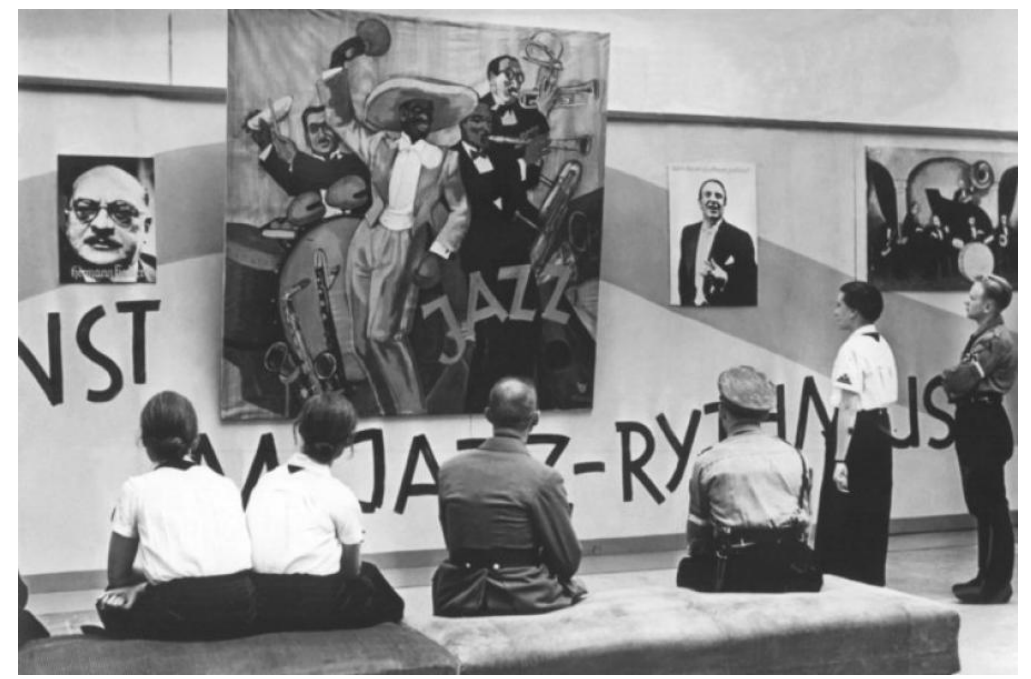

Image 6 - Exhibition Entartete Musik in detail: musicians and composers linked to Judaism, jazz and the North American swing.

Source: United States Holocaust Memorial Museum (USHMM).

Finally, after months of exhibitions open to the public, the sale of these works ended up constituting an important source of profits for the state in wartime, as pointed out by Miranda (2007):

During the series of exhibitions, Hitler realized that selling the works could earn good money for the party's coffers. Part of them was auctioned in 1939 at the Fischer Gallery in Lucerne. Several important works ended up saved in the hands of collectors. [...] But what had no exchange or sale value by the standards set by Nazism was destroyed. At one time, on March 20, 1939, 1004 paintings, 3825 watercolors, and so many other works were burned (MIRANDA, 2007, p. 36).

From these exhibitions, we observe how art was used in the formation process of German population in the Third Reich. This kind of education - hierarchical, doctrinal, and authoritarian - was widely criticized by the Frankfurt School intellectuals, especially from the Critical Theory of Theodor Adorno (1903-1969) and Max Horkheimer (1895-1973)16. Like Jews and Marxists, these German intellectuals were persecuted by the Nazis and ended up in exile in countries in Europe and America, from where they made strong attacks on the semi formation ${ }^{17}$ instituted by the Nazis. For the authors, there would be a moral responsibility of philosophy for the rise of fascism, totalitarian regimes - Benito Mussolini

${ }^{16}$ The origin of the term "Critical Theory" is found in Max Horkheimer's article Traditional Theory and Critical Theory. The term was used to evade the terminology "historical materialism" used by Orthodox Marxism. The "critical" component of the theory aimed to overcome the limits of positivism, materialism, and economic determinism. In Adorno and Horkheimer's view, Marxian theory was current, but it should be updated incorporating philosophical, cultural, political and psychological aspects (HORKHEIMER, 1989).

17 In his Semi formation Theory, Adorno explains that the word semi would not be half, but an impediment, that is, it is the capitalist society itself that prevents the full development of culture, which semi forms rather than forming subjects. Supported by school, family, and the state, deforming or semi formative attitudes destroy autonomous formation and affect society, not just the field of education. Similarly, this semi formation would reach not only the intellect (reason), but the sensory and the corporeal (ADORNO, 2010). This debate on the regressive character of culture was also sketched in the classical work Dialectic of Enlightenment, published in 1944 from the partnership between Adorno and Horkheimer (ADORNO; HORKHEIMER, 2006). 
in Italy in 1922, Joseph Stalin (1878-1953) in the Soviet Union in 1924, Adolf Hitler in Germany in 1933 - the genocides culminating in the Auschwitz concentration camps, as well as the outbreak of the two great World Wars (PUCCI; ZUIN; LASTÓRIA, 2016). In Education after Auschwitz, Adorno points out that the conditions for the spread of violence and barbarism continued to exist in the postwar context, which is why critical philosophy and education would play a key role in resisting to semi formation:

Any debate about educational goals lacks meaning and importance in the face of this goal: that Auschwitz should not be repeated. It was the barbarism against which all education is directed. There is talk of the threat of a regression to barbarism. But this is not a threat, because Auschwitz was the regression; barbarism will continue to exist if the fundamental conditions that generate this regression persist. That is what terrifies. Despite the current lack of visibility of misfortunes, social pressure continues to impose itself (ADORNO, 2000, p. 118-119).

In this sense, Adorno proposes a political and reflexive education, focusing on the autonomy of the subjects: an educational process opposed to the one that culminated in Auschwitz concentration camps, the result of a supposed reason, turned into a blind doctrine in the end. Only by combating semi formation could men humanize and question themselves, as opposed to 'hardening', bourgeois coldness, intolerance, barbarism, and insensitivity to the differences that marked the education of totalitarian regimes. In the words of Adorno (2000):

This educational idea of severity, which many may recklessly believe, is totally mistaken. The idea that virility consists in a maximum degree of pain-bearing capacity has long been the facade of a masochism which - as psychology has shown - is very easily identified with sadism. The praised goal of "being hard" in such an education means indifference to pain in general. Even the pain of the other is not so different from the pain of himself. He who is severe with himself acquires the right to be severe with others, taking revenge on the pain whose manifestations he needed to conceal and repress. This mechanism needs to be made conscious as well as the promotion of an education that does not reward pain and the capacity to endure it, as it used to be. In other words, education must take seriously what philosophy has long known: that fear must not be repressed. When fear is not repressed, when we allow ourselves to be as afraid as this reality requires, then precisely this way will probably disappear most of the deleterious effects of unconscious and repressed fear (ADORNO, 2000, p. 127-128).

Criticisms grounded by Theodor Adorno broadened the scope of research within the field of philosophy and sociology, not only for promoting an interdisciplinary approach, overcoming the economicism and determinism of orthodox Marxist theory, but for innovating and giving new meaning to the Critical Theory in the postwar context (BRONNER, 1997). His denunciations of the dangers of fascism and his attack on totalitarian education show us the problems posed by a semi formation model based on rigidity, hierarchy, authoritarianism, the use of art in the service of ideological propaganda, 
the militarization of youth, the blind obedience to orders, the diminishing of the subject to the detriment of a larger collective and the abandonment of philosophical conceptions of ethics.

The rescue of the critical and political potential of education based on a "critical selfreflection of social conditioning" and a "criticism of the ideological way of promoting semi culture" could contribute to the "realization of the formative experience and, consequently, of emancipation" (GOMES, 2010, pp.204-205). Similarly, the Adornian proposal to resist the process of semi formation through critical education remains current ${ }^{18}$, considering the survival of fascist ideology even after the deaths of leaders Benito Mussolini and Adolf Hitler. After all, was Theodor Adorno "who asked if it was still possible to write poetry after Auschwitz. It was he who shouted against the 'liquidation of the subject'" (BRONNER, 1997, p. 219-220).

\section{Final considerations}

Through the exhibitions Entartete Kunst and Entartete Musik, we observe the education and art used in the service of semi formation, contributing to the construction and reaffirmation of the ideals of Nazi fascism, racial superiority, anti-communism, antiSemitism, xenophobia, anti-modernism and eugenics - an educational and aesthetic model that censors, oppresses, and encourages hatred and intolerance. In contrast, Adorno's aesthetic theory and his theoretical contributions to the field of Education stress the need for approximation between critical philosophy and art, in order to avoid its being used in the name of the semi formation of subjects - as in the case of Nazi exhibitions - because "a priori, prior to his works, art is a critique of the fierce seriousness that reality imposes on human beings" (ADORNO, 2001, p. 13).

We believe that Adorno's Critical Theory comprises a theoretical possibility for the construction of a critical education model, constituting at the same time a denunciation and a struggle against the semi formation that persists in time, even after the fall of the totalitarian regimes that devastated the world during the first half of the twentieth century. By presenting these issues and bringing to light the main elements that made up education and art in the Third Reich, we do not intend to exhaust the subject in question, considering its relevance and complexity. However, supported by the authors who focused on the

\footnotetext{
${ }^{18}$ On the relevance of the critical theorists of the Frankfurt School and the critiques of the semi formation see Grushka (2014), Pucci, Zuin and Lastória (2010), Pucci, Costa and Durão (2012), Zuin, Lastória and Gomes (2012).
} 
theme of Nazi education, we aim to contribute to denounce the dangers of fascism in the field of Education, defending, as Adorno, the construction of an emancipatory education, where art and philosophy are placed at the service of a critical formation and the overcoming of the state of barbarism.

\section{References}

ADORNO, T.W. Educação e Emancipação. Tradução Wolfgang Leo Maar. $2^{a}$ ed. Rio de Janeiro/São Paulo: Editora Paz e Terra S. A., 2000.

ADORNO, T. W. A arte é alegre? In: RAMOS-DE-OLIVEIRA, N.; ZUIN, A. Á. S.; PUCCI, B.(Orgs.). Teoria crítica, estética educação. Campinas: Unimep, 2001.

ADORNO, T.W. Teoria da Semiformação. In: PUCCI, ZUIN E LASTÓRIA (orgs). Teoria Crítica e inconformismo: novas perspectivas de pesquisa. Campinas-SP: Autores Associados, 2010. pp.7-40.

ADORNO, T.W.; HORKHEIMER, M. Dialética do Esclarecimento: fragmentos filosóficos. Tradução Guido Antônio de Almeida. Rio de Janeiro: Jorge Zahar Ed., 2006.

BARTOLETTI, S.C. Juventude hitlerista: a história dos meninos e das meninas nazistas e a dos que resistiram. Tradução de Beatriz Horta. Rio de Janeiro: Relume-Dumará, 2006.

BRONNER, S.E. Da Teoria Crítica e seus teóricos. Tradução Tomás R. Bueno, Cristina Meneguelo. Campinas, SP: Papirus, 1997.

BURLEIGH, N. Mirage: Napoleon's Scientists and the Unveiling of Egypt. $1^{\text {a }}$ ed. New York: Harper Perennial, 2007.

CAMBI, F. História da Pedagogia; tradução de Álvaro Lorencini. São Paulo: Fundação Editora da Unesp (FEU), 1999.

COHEN, P. Undergångens arkitektur (Arquitetura da Destruição); narração Bruno Ganz (documentário, cor, 119 min.). Suécia, 1989.

CONTIER. A.D. Arte e Estado. Música e Poder na Alemanha dos anos 30. Revista Brasileira de História. São Paulo, v 8, n¹5, pp. 107-122. set/fev 1988.

CUNO, J. Who Owns Antiquity? Museums and the Battle over Our Ancient Heritage. New Jersey: Princeton University Press, 2008.

DHM. Deutsches History Museum. Disponível em https://www.dhm.de/lemo/kapitel/nsregime/kunst-und-kultur/entartete-kunst.html . Acesso em 10/11/2020.

ELIAS, N. Os alemães: a luta pelo poder e a evolução do habitus nos séculos XIX e XX. Tradução de Álvaro Cabral. Rio de Janeiro: Jorge Zahar Ed., 1997.

FERREIRA, C.S. Restituição dos bens culturais retirados no contexto do colonialismo: instrumento de desenvolvimento e de diálogo intercultural. Edições Universitárias Lusófonas. Cadernos de Sociomuseologia, v.47 n³, pp. 109-129, junho de 2014. 
FRIEDLANDER, $\mathrm{H}$. The origins of Nazi genocide. From euthanasia to the Final Solition. Chapel Hill and London: University of North Carolina Press, 1995.

GHDI. Germany History Documents and Images. Disponível em http://germanhistorydocs.ghi-dc.org/sub_image.cfm?image_id=2082 . Acesso em $10 / 11 / 2020$.

GOMBRICH, E.H. A História da arte. $1^{\text {a }}$ ed. Rio de Janeiro: LTC, 2013.

GOMES, L.R. Teoria Crítica, Educação e política. In PUCCI, B.; A.S.ZUIN; L.A.C.N.LASTÓRIA (orgs). Teoria crítica e inconformismo: novas perspectivas de pesquisa. Campinas-SP: Autores Associados, 2010. pp. 197-215.

GRUSHKA, A. Frieza burguesa e educação: a frieza como mal-estar moral da cultura burguesa na educação. Campinas, SP: Autores Associados, 2014.

HITLER, A. Minha Luta (Mein Kampf). Tradução Klaus von Punchen. $1^{\text {a }}$ Edição Histórica. São Paulo: Centauro, 2016.

HOBSBAWM, E.J. A Era dos Extremos: o breve século XX (1914-1991). Tradução Marcos Santarrita. Revisão técnica Maria Célia Paoli. São Paulo: Companhia das Letras, 1995.

HORKHEIMER, M. Teoria Tradicional e Teoria Crítica. In: HORKHEIMER, M.; ADORNO, T.W.; Textos Escolhidos. São Paulo: Nova Cultural, 1989.

KNUTH, R. Libricide: the regime-sponsored destruction of books and librarys in the twentieth century. Wesport: Praeger Publishers, 2003.

KRACAUER, S. De Cagliari a Hitler. Historia Psicológica del cine alemán. Traducción de Hector Grossi. Barcelona: Ediciones Paidós, 1985.

MIRANDA, S. Arte Degenerada: Obras inimigas. Revista Aventuras na História. São Paulo, n47, p. 36, julho de 2007.

PUCCI, B.; A.S. ZUIN; L.A.C.N. LASTÓRIA (orgs). Teoria crítica e inconformismo: novas perspectivas de pesquisa. Campinas-SP: Autores Associados, 2010.

PUCCI, B.; ZUIN, A.; LASTÓRIA, L. 10 lições sobre Adorno. $1^{a}$ ed. São Paulo: Editora Vozes, 2016.

PUCCI, B.; COSTA, B.C.G; DURÃO, F.A. (orgs). Teoria crítica e crises: reflexões sobre cultura, estética e educação. Campinas-SP: Autores Associados, 2012.

RIEFENSTAHL, L. Triumph des Willens (Triunfo da Vontade); (documentário, preto e branco, 114 min.) Alemanha, 1935.

SHIRER, W.L. The Rise and Fall of the Third Reich. New York: Simon \& Schuster, 1990.

UNESCO. Convention for the Protection of Cultural Property in the Event of Armed Conflict with Regulations for the Execution of the Convention 1954. HAIA: UNESCO, 1999. Disponível em http://portal.unesco.org/en/ev.phpURL_ID=13637\&URL_DO=DO_TOPIC\&URL_SECTION=201.html . Acesso em 10/11/2020.

USHMM. United States Holocaust Memorial Museum. Disponível em https://www.ushmm.org/information/exhibitions/online-features/collections- 
highlights/julien-bryan/nazi-germany-1937/1937-munich-exhibition-of-degenerate-art Acesso em 10/11/2020.

ZUIN, A.S.; LASTÓRIA, L.A.C.N.; GOMES, L.R. (orgs). Teoria crítica e formação cultural: aspectos filosóficos e sociopolíticos. Campinas-SP: Autores Associados, 2012.

' Doutorando em Educação pela Universidade Federal de São Carlos (UFSCar). Mestre em Educação e graduado em História pela Universidade Estadual Paulista (UNESP).

ii Mestre em Educação pela Universidade Estadual Paulista (UNESP). Graduada em Inglês pela Universidade Metodista de Piracicaba (UNIMEP).

iii Pós-doutor em ciências da educação pela J. W. Goethe Universität em Frankfurt am Main (Alemanha). Doutor em Educação na área de Filosofia, História e Educação pela Universidade Estadual de Campinas (UNICAMP). Mestre em Educação na área de Filosofia e História da Educação pela Pontifícia Universidade Católica de São Paulo (PUC-SP). Licenciado em Filosofia pela Pontifícia Universidade Católica de Campinas (PUC-Campinas).

Como citar esse artigo:

ROITBERG, Guilherme Prado; BAPTISTA, Fabiana Maria; GOMES, Luiz Roberto. Expositions of 'degenerate' art and music in nazi Germany: reflections on totalitarian aesthetics and education. Revista Digital do LAV, Santa Maria: UFSM, v. 13, n. 3, p. 97-133, set./dez. 2020. 